\title{
Evidence for decreasing sperm count in African population from 1965 to 2015
}

\author{
Pallav Sengupta ${ }^{1,3}$, Uchenna Nwagha ${ }^{2}$, Sulagna Dutta ${ }^{1}$, Elzbieta Krajewska-Kulak ${ }^{3}$, Emmanuel Izuka $^{4}$
}

1. Physiology, Lincoln University College, Petaling Jaya, Malaysia

2. Department of of Physiology, Obstetrics and Gynecology, College of Medicine, University of Nigeria, Enugu Campus, Nigeria

3. Integrated Medical Care, Medical University of Bialystok, Bialystok, Poland

4. Department of Obstetrics and Gynecology, College of Medicine, University of Nigeria, Enugu Campus, Nigeria

\begin{abstract}
Purpose: This meta-analysis, following our previous reports those documented an overall $57 \%$ diminution in mean sperm concentration around the globe over past 35 years and 32.5\% decline in past 50 years in European population, attempts to report the declining trend of sperm concentrations in African population between 1965 and 2015.

Methods: In the course of retrieval of data following MOOSE guidelines and PRISMA checklist, we found a total of fourteen studies that have been conducted during that period on altering sperm concentration in the African male.

Results: Following analysis of the data, a time-dependent decline of sperm concentration $(r=-0.597, p=0.02)$ and an overall $72.6 \%$ decrease in mean sperm concentration was noted in the past 50 years. The major matter of concern is the present mean concentration $\left(20.38 \times 10^{6} / \mathrm{ml}\right)$ is very near to WHO cut-off value of 2010 of $15 \times 10^{6} / \mathrm{ml}$. Several epidemic diseases, genital tract infection, pesticides and heavy metal toxicity, regular consumption of tobacco and alcohol are reported as predominant causative factors.
\end{abstract}

Conclusion: This comprehensive, evidence-based meta-analysis and systematic review concisely presents the evidence of decreased sperm concentration in the African male over past 50 years with possible causative factors to serve the scientific research zone related to male reproductive health.

Keywords: Semen quality, sperm concentration, sperm count.

DOI: https://dx.doi.org/10.4314/ahs.v17i2.16

Cite as: Sengupta P, Nwagha U, Dutta S, Krajewska-Kulak E, Izuka E. Evidence for decreasing sperm count in African population from 1965 to 2015. Afri Health Sci. 2017;17(2): 418-427. https:// dx.doi.org/10.4314/abs.v17i2.16

\section{Introduction}

A worldwide decline in sperm count has been presented vastly in past few decades through several studies ${ }^{1,2}$. The deterioration of semen quality was first noted in 1974 by Nelson and Bunge ${ }^{3}$. In 1992, Carlsen et al. reported a global decline in sperm counts in a meta-analysis of 61 studies between 1938 and 1990 evaluating the semen analyses of 14,947 presumably fertile men from 23 countries $^{4}$. In that analysis, they have found significant declines

\section{Corresponding author:}

Pallav Sengupta,

Physiology Unit, Faculty of Medicine

Lincoln University College, Malaysia

And Post-Doctoral Fellow

Integrated Medical Care

Medical University of Bialystok, Poland

Email: pallav@lincoln.edu.my in sperm count in the United States, Europe, and Australia, but no such decline in non-Western countries. Similar declines were also proclaimed by numerous other studies, but were unable to establish a clear cause ${ }^{5,6}$ But, since then the reports published regarding the changes in human semen parameters were so far inconsistent: Nieschlag et al. ${ }^{7}$ reported no changes in any parameter ${ }^{7}$, while $\mathrm{Ng}$ et al. ${ }^{8}$ revealed significantly different seminal volumes in different age groups ${ }^{8}$. Recently, Rolland et al. ${ }^{9}$ in their analysis showed $32 \%$ decline in sperm count from 1989 to $2005^{9}$. In our recent articles, we have also reported decline in semen volume ${ }^{10}$ and sperm count ${ }^{11}$ in males over past few decades.

Reports regarding the altered sperm concentration in African sub-continent is very limited. The first document regarding altered sperm concentration of the African population after 1965 was put forward by Chukudebelu et al. ${ }^{12}$. But during 1965-1979, there is no study recount- 
ing altering sperm concentration in Africa. But, there are plenty of articles which report causes and risk factors of male infertility in the African population. These reports showed that significantly increased serum follicle stimulating hormone $(\mathrm{FSH})^{13}$ and decreased inhibin $\mathrm{B}^{14}$ may result in testicular spermatogenic dysfunction ${ }^{15}$. Changes in sperm count can also occur after occupational and environmental exposure to toxic agents ${ }^{16-19}$ or from the predisposing factors of the host, such as age ${ }^{20-22}$. Thus, the objective of this meta-analysis was to build-up a substantial idea regarding alterations in sperm concentration in the African population by picking the scattered reports of past 50 years, moulding them in sequential pattern, statistically analysing and through the systematic review looking over the linking factors of decreased sperm concentration.

\section{Data extraction and data anaysis}

Research articles on humans published in English from 1965 to 2015 were included in this report ${ }^{23-36}$ (Table 1$)$.

Table 1. Studies on changes of sperm concentrations in different age groups in past 50 years in Africa.

\begin{tabular}{|c|c|c|c|c|c|}
\hline Country & Population & $\begin{array}{l}\text { Sample size } \\
\text { (n) }\end{array}$ & $\begin{array}{l}\text { Male age definition } \\
\text { (range/ mean/group, } \\
\text { in years) }\end{array}$ & $\begin{array}{l}\text { Direction of effect } \\
\text { with increasing age }\end{array}$ & Study \\
\hline Nigeria & Cohort study & 53 & $20-45$ & $\downarrow(\mathrm{P}<0.01)$ & Lapido, 1980 \\
\hline Egypt & Andrology lab & 45 & $19-53$ & $\downarrow(\mathrm{P}<0.01)$ & $\begin{array}{l}\text { Shaarawy and } \\
\text { Mahmoud, } 1982\end{array}$ \\
\hline Libya & Infertility clinic & 1500 & $20-45$ & $\downarrow(\mathrm{P}<0.01)$ & Sheriff, 1983 \\
\hline Nigeria & Cohort study & 100 & $20-45$ & $\downarrow(\mathrm{P}<0.01)$ & Osegbe et al., 1986 \\
\hline Libya & Cohort study & 10 & No age data & $\downarrow(\mathrm{P}<0.01)$ & Sheriff, 1987 \\
\hline Tanzania & Andrology lab & 120 & $19-55$ & $\downarrow(\mathrm{P}<0.01)$ & Kirei, 1987 \\
\hline Nigeria & Cohort study & 20 & $19-53$ & $\downarrow(P<0.001)$ & $\begin{array}{l}\text { Sobowale \& } \\
\text { Akiwumi, } 1989\end{array}$ \\
\hline Nigeria & Andrology lab & 21 & $19-24$ & $\downarrow(\mathrm{P}<0.05)$ & Nnatu et al., 1991 \\
\hline Libya & Cohort study & 1250 & $19-53$ & $\downarrow(\mathrm{P}<0.01)$ & $\begin{array}{l}\text { Sheriff and Legnain, } \\
1992\end{array}$ \\
\hline Nigeria & Infertility clinic & 170 & $25-40$ & $\downarrow(\mathrm{P}<0.001)$ & Ugwuja et al., 2008 \\
\hline Tunisia & Infertility clinic & 2940 & $20-45$ & $\downarrow(\mathrm{P}<0.001)$ & Feki et al., 2009 \\
\hline Nigeria & Cohort study & 106 & $20-45$ & $\downarrow(\mathrm{P}<0.01)$ & Akande et al., 2011 \\
\hline Nigeria & Infertility clinic & 316 & $20-40$ & $\downarrow(\mathrm{P}<0.05)$ & Jimoh et al., 2012 \\
\hline Tunisia & Andrology lab & 116 & $\begin{array}{l}\text { Males of } \\
\text { mean age } 32.74\end{array}$ & $\leftrightarrow(\mathrm{NS})$ & $\begin{array}{l}\text { Hadjkacem Loukil et } \\
\text { al.,2015 }\end{array}$ \\
\hline
\end{tabular}

Data are represented as Mean(SD); $\downarrow=$ decrease; $\uparrow=$ increase; $\leftrightarrow=$ no change; NS=not significant at $\mathrm{P}<0.05$, no $P$ value indicates that no statistical testing was done

We also included the reports of Carlsen et al. (1992), i.e. reports from 1965 to $1992^{4}$. We selected publications about sperm concentration, with pre-defined criteria for inclusion and exclusion, as follows. [1] The non-Carlsen studies published during 1965 to 2015 were identified by using Medical Subject Headings (MeSH) of electronic databases which included Medline, National Library of Medicine, Bathesda, MD with the key words: sperm count, sperm density, sperm concentration, semen quality, male infertility and semen analysis. [2] Relevant literature on changes of the sperm concentration and its influence on future natural and assisted conception cycles were retrieved. [3] Data of the subjects with clinical problems were excluded. [4] Studies with insufficient numbers of subjects $(\mathrm{n}<5)$ were excluded. We followed Meta-analy- ses of Observational Studies in Epidemiology (MOOSE) guidelines ${ }^{37}$ and Preferred Reporting Items for Systematic Reviews and Meta-analyses (PRISMA) checklist ${ }^{38}$, 2009 to extract the data using the above mentioned electronic databases (Table 2). In each case sperm concentration and its outcome were evaluated. Analytic epidemiological studies were emphasized. Therefore, the current analysis was based on 14 African studies published in 1965-2015. For simple statistical analyses Microsoft Excel v.2013 was used and correlation and regression analyses of data were done using StatSoft. (2011) and SPSS v.22.0 to calculate correlation coefficient and it was considered to be significant if $\mathrm{p}$ was $<0.05$ or $<0.001^{39}$. Mean sperm concentrations of all 14 reports were also analyzed with linear regression weighted by number of subjects included in the individual publications. 
Table 2. Flow chart of study selection according to MOOSE guidelines.

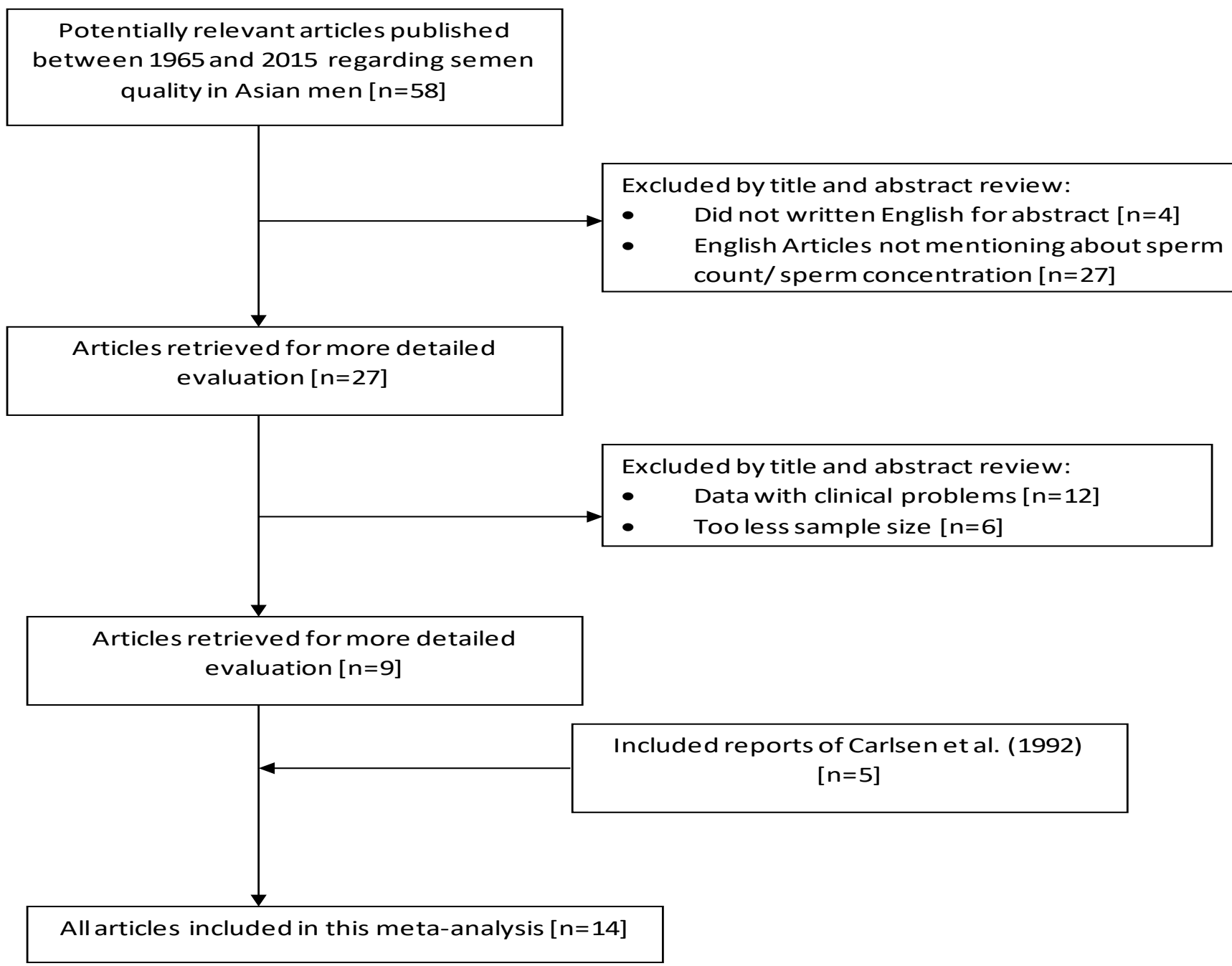

State of affairs: past 50 years

\section{African scenario}

In 1991, WHO had estimated that almost 20-35 million couples were infertile in Africa ${ }^{40}$. Nigeria is suggested to have been suffering from highest infertility problems among the other African regions, the male infertility factor accounting for $40-50 \%$. The degree of infertility and its cause vary from place to place. These are evident from the study pursued in mid-Western Nigeria which brought to the lime light that about $50 \%$, of the 780 couples under evaluation, differed in the causes of their infertility ${ }^{41}$. Study associated with South-Western Nigeria reported that $42.4 \%$ infertility resulted from the male factor ${ }^{42}$.

During the retrieval of relevant documents, we found only fourteen studies which had been conducted on alterations of sperm concentration of African population in the last 50 years. The outcome of these studies is represented in Table 1. Most of the reports were based on epidemiological studies (43\%), and others included andrology laboratories (29\%) and infertility clinics (29\%). Among the 14 published research works discussed in this article from 1965 to 2015, most were carried out in Nigeria. Most of the studies used sample size less than 500 men $(79 \%)$ and only three studies included sample size $>1000(21.43 \%)$. Out of 14 reports, 93\% have provided data about the age of subjects; all of these reports depicted significant decrease in sperm concentration from 1965 to 2015 while only one report showed no significant alteration. We also recorded that most of the studies were carried out in Nigeria. A time-dependent decline in sperm concentration was observed from 1965 to 2015 (r $=-0.597, \mathrm{p}=0.02$; Fig 1) that reflected an overall 73\% decrease in sperm concentration (Fig 2). 


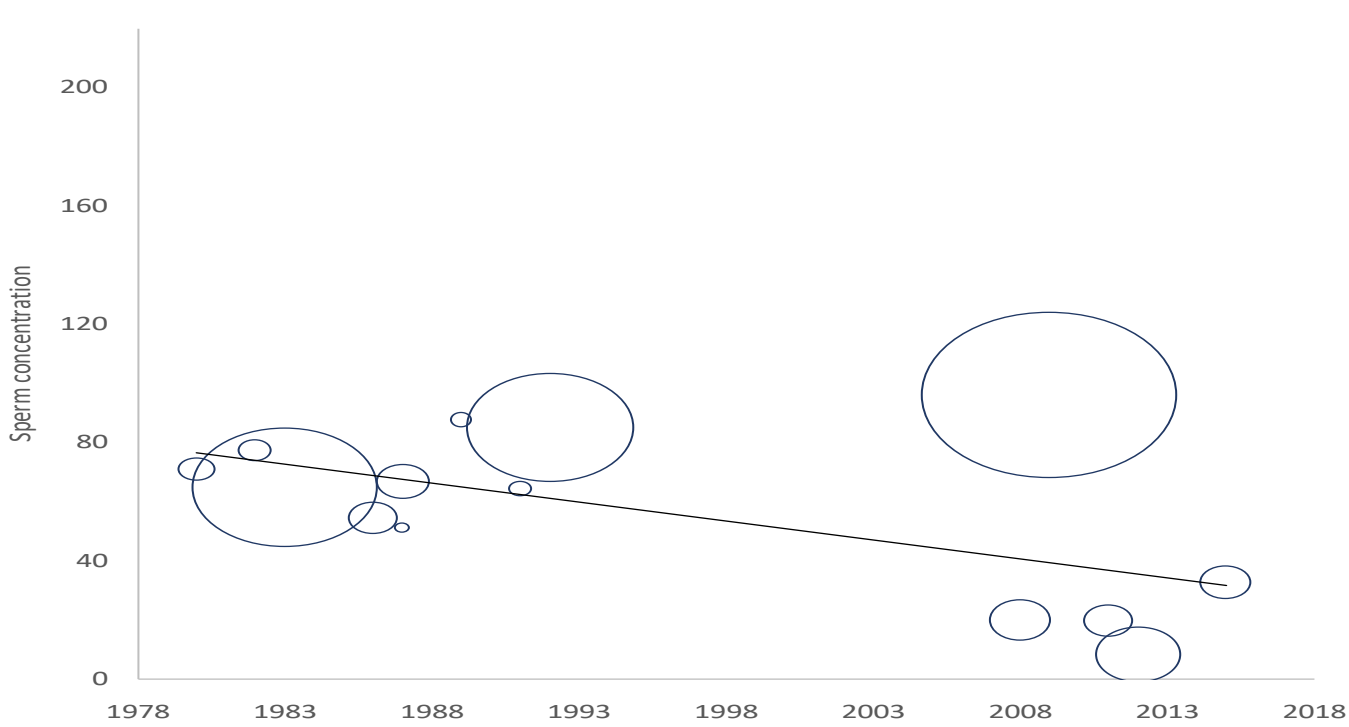

Fig 1. Temporal decline in sperm concentration $\left(\times 10^{6} / \mathrm{ml}\right)$, bubble size corresponds to the number of men in study following Table 1

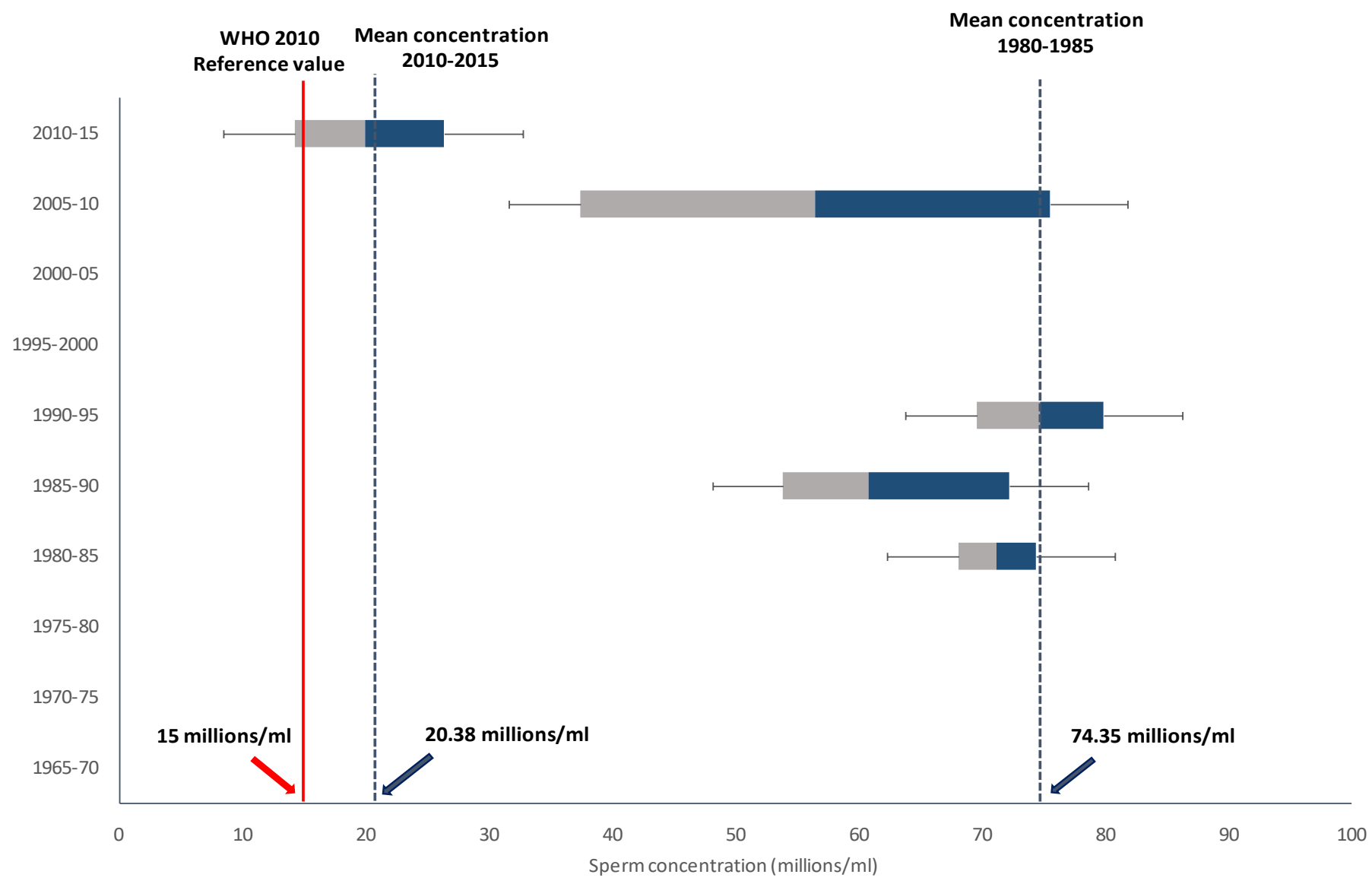

Fig 2. Box and whisker plot of sperm concentration data of African men between 1965 and 2015 with WHO cut-off value (2010).

It is thus understandable that regional variations in reproductive status prevails in Africa and the high rates of male infertility in Nigeria is thought to be due to infec- tions, sexually transmitted diseases and hormonal abnormalities ${ }^{43,44}$. But, the major matter of concern is that the present mean concentration $\left(20.38 \times 10^{6} / \mathrm{ml}\right)$ is very near to WHO cut-off value of 2010 of $15 \times 10^{6} / \mathrm{ml}^{40}$ 


\section{Comparing with global scenario}

In one of our recently published article, we showed a significant decrease in sperm concentration worldwide between 1980 and 2015 from $91.65 \times 10^{6} / \mathrm{ml}$ to $39.34 \times 10^{6} /$ $\mathrm{ml}(\mathrm{r}=-0.313, \mathrm{p}=0.0002)$. It reflected almost $57 \%$ decline in sperm count worldwide from 1980. It also showed that recruitment of larger population for this type of study increased predominantly after $1995^{11}$. In another report, we revealed a time-dependent decline of sperm concentration $(\mathrm{r}=-0.307, \mathrm{p}=0.02)$ in European men from 1965 to 2015 and an overall 32.5\% decrease in mean concentration ${ }^{45}$.

Recent studies on male reproductive system when brought together bring conflicting evidence to the forefront regarding sperm counts with some showing significant decline while some found no change. North America, Europe and Asia were more prone to a declining trend of sperm counts over the years whereas studies based on South America and Australia do not depict such a trend ${ }^{11}$. However, in this present analysis a significant decline in sperm concentration has been noted in the African population. It has been suggested that these regional differences in sperm counts possibly are biologically meaningful. Most of the controversies that aroused from the past clinical studies about semen quality may be partly due to involvement of only few selected groups of men. In many studies, historical data collected for other purposes has been used without close attention to important and specific factors relevant to an analysis of secular or geographical trends.

\section{Possible causative factors}

Although little is known about the causative factors for the decline in sperm count worldwide, significant associations have been reported between impaired semen quality including sperm count, and several of the etiological factors in developing countries especially Africa ${ }^{46}$. We also reported some link factors of declining sperm concentration worldwide ${ }^{11}$, but the proper correlation with a single factor is difficult to establish.

In Africa, it has been reported that some epidemic diseases, like malaria, Schistosomiasis and viral infections play pivotal roles in the declining sperm concentration ${ }^{47,48}$. Yeboah et al. in 1992 reported that in Ghana they found a $12 \%$ higher incidence of inflammatory testicular or prostatic conditions as compared with those found in

African Health Sciences Vol 17 Issue 2, June, 2017
Europeans, suggesting that inflammatory conditions contribute more to male infertility and declining sperm concentrations in Africa. ${ }^{47}$ Genital tract infections and sexually transmitted infections are associated with declining sperm concentrations in African men ${ }^{49,50}$. Okonofua et al. found that infertile and sub-fertile men are more likely than fertile men to report having experienced penile discharge, painful micturition and genital ulcers, yet they are less likely to present to a formal health institution to seek treatment. ${ }^{50}$ Therefore, poor health-seeking behaviour of our African men is key to the declining sperm concentration $^{41,50}$.

Regular alcohol consumption and tobacco smoking are responsible for the declining sperm concentration ${ }^{50}$. Several studies reported that these two factors are the principal causes of hypogonadism and could cause testicular failure ${ }^{51}$. Therefore, it is possible that the increased consumption of alcohol and tobacco smoking could be a contributory factor to the global fertility crisis in the human species ${ }^{52}$. Moreover, tobacco smoking increases intake of cadmium, because the tobacco plant absorbs the metal. Cadmium, being chemically similar to zinc, may replace zinc in the DNA polymerase, which plays a critical role in sperm production ${ }^{53}$. Geographic differences in the amount of naturally occurring cadmium have been correlated with incidence rates of prostate cancer ${ }^{54}$. Major changes in the levels of toxic elements in seminal fluid have been related to abnormal spermatozoa function and fertilizing capacity ${ }^{55}$. Cadmium has beendetected in significantly high levels in serum of men who were smokers and thus implicated this metal as one of the causes of asthenoteratozoospermia ${ }^{55}$.

Cigarette smoking is an important variable when considering the effect of both lead and cadmium exposure on human health. A single cigarette has been reported to contain $1.5 \mu \mathrm{g}$ of cadmium. Moreover, one tenth of the metal content of a cigarette is inhaled ${ }^{56}$. Unlike in most developed nations, there are no smoking restrictions in Africa. Even where there are, they are not obeyed. Cumulative evidence suggests that cigarette smoking has a deleterious effect on male fertility by reducing sperm production, motility, and increasing the number of abnormal sperm ${ }^{57}$. Smokers are $60 \%$ more likely to be infertile compared to non-smokers. Cigarette smokers were also shown to have higher levels of circulating estradiol and decreased levels of LH, FSH, and prolactin compared to non-smokers, all of these negatively impact spermatogenesis ${ }^{57}$. 
Emokpae et al. in Kano, Nigeria reported that endocrine abnormalities are common in the infertile males ${ }^{58}$. Hormonal abnormalities were detected in $22 \%$ of oligospermic, $40.7 \%$ of severe oligospermic, and 43 of azoospermic subjects. Similarly, hormonal imbalance was also found by Ozoemena et al. in Enugu to be significantly associated with declining sperm concentration and male infertility ${ }^{59}$. They demonstrated that as much as $80.1 \%$ of their subjects were found to have a hormonal imbalance and recommended that hormonal profile should be considered as the gold standard for diagnosis and management of male infertility. An observational retrospective study conducted on 1,201 men (mean age of 35.7 years) in Northern Nigeria investigated for infertility at University of Maiduguri Teaching Hospital, over a two-year period, (2004-2006) showed that 96 (7.9\%), underwent hormonal assessment because of abnormalities of their sperm counts. $68(71 \%)$ patients had primary infertility and $72(75 \%)$ had azoospermia. $88(92 \%)$ patients had abnormal hormonal assays, giving a prevalence of endocrine abnormality of $7.3 \%{ }^{60}$.

Therefore, endocrinopathy is also common among infertile Nigerian men as with their counterparts elsewhere. However, the prevalence of endocrinopathy of $7.3 \%$ was lower than that reported from Kenya ${ }^{61}$, an African country, but higher than that reported in Brazil a developing country like Nigeria ${ }^{62}$.

Numerous anti-oxidant nutrients such as vitamin C, vitamin E, glutathione and co-enzyme Q10 have been documented in several studies as having modulatory effects on sperm parameters ${ }^{52,63}$. These positive effects may not be observed in Africa because of the well-recognised deficiency of protective micronutrients in this region ${ }^{64}$. Studies have shown that the concentration of ascorbic acid in seminal plasma directly reflects dietary intake, and lower levels of vitamin $\mathrm{C}$ may lead to infertility and increased damage to the sperm genetic material ${ }^{65}$. Ebesunun et al. determined ascorbate levels in the plasma of 27 Nigerian males with inadequate spermatogenesis ${ }^{66}$. There were significant decreases in the seminal and plasma ascorbic acid concentration in males who had inadequate spermatogenesis compared with the control values and the author concluded that semen ascorbate levels may play a significant role in reduced sperm characteristics in these patients $^{52,66}$. Selenium and glutathione are essential to the formation of phospholipid glutathione peroxidase, an enzyme present in spermatids, which becomes a structural protein comprising over $50 \%$ of the mitochondrial capsule in the midpiece of mature spermatozoa. Deficiencies of either substance can lead to instability of the midpiece, resulting in defective motility ${ }^{52,63}$. Akinloye et al. in their study observed a significant inverse correlation between serum selenium level and sperm count. Similarly, seminal plasma selenium correlated with spermatozoa motility, viability, and morphology ${ }^{67}$.

The spermatotoxic effects of dibromochloropropane (DBCP), a nematocide widely used in agriculture was reported in the early 1960s in rodents by animal toxicologist but their report went essentially unnoticed until the late 1970s when oligospermia and azoospermia were reported in manufacturing plant workers and pesticides applicators $^{68}$. It was noted that there was limited childbearing among the workers after they started working in DBCP production. About half of the DBCP-exposed azoospermic men remained that way for many years suggesting that all of the stem spermatogonia may have been compromised. 71 others experienced a recovery in their sperm count, but in some cases the recovery did not occur until 3 to 6 years later ${ }^{68}$. Furthermore, the men had high levels of FSH and LH in serum indicating that DBCP action is directly on the Leydig cells causing alterations in androgen production and action ${ }^{68}$. Other pesticides such as dichloro-diphenyl-trichloroethane (DDT), endosulphan, and organophosphorus pesticides i.e. malathion, have been reported to show male-mediated adverse reproductive outcomes such as abortions, stillbirths, congenital defects etc. among occupationally exposed workers ${ }^{69}$.

A significantly higher level of asthenozoospermia and teratozoospermia was found in 2, 4-dichlorophenoxy acetic acid exposed workers as compared to unexposed control subjects ${ }^{70}$. Although DDT production has been banned in the United States for more than 2 decades, new factories are still being built to produce in some developing nation. The presence of these chemicals in some developing countries is of concern since they are probably accumulating to harmful levels. Ibeh et al. reported higher concentrations of aflatoxin B1 (AFB1) in the semen of infertile Nigerian men than those levels in fertile controls and concluded that the consumption of AFB1 contaminated diets may predispose to male infertility in Nigeria ${ }^{71}$. Over five billion people in developing countries worldwide are at risk of chronic exposure to AFB1 through 
food products contaminated by the fungal moulds. The infertile men with aflatoxin in their semen showed a higher percentage of spermatozoa abnormalities (50\%) than the fertile men (10-15\%). The above observations therefore suggest that pesticides, industrial chemicals and mycotoxins like aflatoxins might be implicated in the declining fertility of the African men ${ }^{71}$.

A number of occupations are being reported as risk factors for male infertility. For example, an insult to spermatogenesis has been reported among professional drivers who are exposed to the products of fuel combustion, noise, vibration, emotional stress, physical load on the pelvic organs and increased temperature in the pelvis because of prolonged sitting ${ }^{72}$. Intense exposure to heat in the workplace e.g. working in furnaces or in bakeries, long soaks in the bath tub, use of laptops, and excessive bicycling can cause the temperature in the scrotum to increase enough to impair sperm production. Welders are also at risk due to their exposure to heat, solvents, heavy metals and noise ${ }^{72}$. Men who wear tight pants which hold the testes close to the body also vulnerable to these defects ${ }^{73}$. Noticeable improvement in sperm count has been observed when the tight underwear is discarded.

\section{Conclusion}

The current meta-analysis, with pertinent evidence reports an overall $73 \%$ decline in sperm concentration in African men over past 50 years and the current concentration is very near to WHO cut-off value of 2010 which is a major issue of concern. It also explains the major possible causes of the declining trend. Poorly treated sexually transmitted infections (STIs) and hormonal abnormalities, consumption of excessive alcohol and tobacco smoking are reported as the major causes. But, according to the published articles describing the link factors of male infertility in Africa, exposure to pesticides and heavy metals are the principal triggers of decreased sperm concentration. However, as more than one factor is involved in this decreasing trend, correlation with a single factor is difficult to establish. Conceivably in future with the development of more sensitive biomarkers, we will be able to relate these factors with decreasing sperm concentration precisely.

\section{Acknowledgements}

The authors are thankful to Datuk, Dr. Abdul Gani Bin Mohammed Din, Dean, Faculty of Medicine and Deputy Vice Chancellor (Academic), Lincoln University College and Prof. Dr. Amiya Bhaumik, CEO and Vice Chancellor, Lincoln University College for their kind support and encouragement. Authors are also thankful to Dr. Sandeep Poddar, Research Manager, Lincoln University College for his valuable suggestions during this research work.

\section{Conflict of interest}

None

\section{Funding source}

None

\section{References}

1. Sengupta P. Current trends of male reproductive health disorders and the changing semen quality. Int J Prev Med 2014;5:1-5 PubMed .

2. Sengupta P. Recent trends in male reproductive health problems. Asian J Pharm Clin Res 2014;7:1-5.

3. Nelson CMK, Bunge RG. Semen analysis-evidence of changing parameters of male fertility potential. Fertil Steril 1974;25:503-507 PubMed .

4. Carlsen E, Giwercman A, Keiding N, Skakkebaek NE. Evidence for decreasing quality of semen during past 50 years. Brit Med J 1992;305:609-613 PubMed .

5. Swan SH, Elkin EP, Fenster L. Have sperm densities declined? A reanalysis of global trend data. Environ Health Perspect 1997;105:1228-1232.

6. Auger J, Kunstmann JM, Czyglik F, Jouannet P. Decline in semen quality among fertile men in Paris during the past 20 years. New Eng J Med 1995;332:281-285 PubMed. 7. Nieschlag E,Lammers U, Freischem C, Langer K, Wickings E. Reproductive functions in young fathers and grandfathers. J Clin Endocrinol Metab 1982;55:676-681.

8. Ng KK, Donat R, Chan L, Lalak A, Pierro ID, Handelsman DJ. Sperm output of older men. Hum Reprod 20014;19:1811-1815.

9. Rolland M, Le Moal J, Wagner V, Royère D, De Mouzon J. Decline in semen concentration and morphology in a sample of 26609 men close to general population between 1989 and 2005 in France. Hum Reprod 2013;28:462470 PubMed .

10. Sengupta P. Reviewing reports of semen volume and male ageing in last 33 years: from 1980 through 2013. Asian Pac J Repro 2015;4:242-246 PubMed .

11. Sengupta P, Dutta S, Krajewska-Kulak E. The disappearing sperms: analysing the reports published between 1980 and 2015. Am J Men's Health 2016: doi: $10.1177 / 1557988316643383$. 
12. Chukudebelu WO, Esege N, Megafu U. Etiological factors in infertility in Enugu, Nigeria. Infertility 1979;2:193-200.

13. Luetjens CM, Rolf C, Gassner P, Werny JE, Nieschlag E. Sperm aneuploidy rates in younger and older men. Hum Reprod 2002;17:1826-1832 PubMed .

14. Mahmoud AM, Goemaere S, El-Garem Y, Van Pottelbergh I, Comhaire FH, Kaufman JM. Testicular volume in relation to hormonal indices of gonadal function in community-dwelling elderly men. J Clin Endocrinol Metab 2003;88:179-184.

15. Sengupta P, Banerjee R. Environmental toxins: alarming impacts of pesticides on male fertility. Hum Exp Toxicol 2014;33:1017-1039 PubMed .

16. Dutta S, Joshi KR, Sengupta P, Bhattacharya K. Unilateral and bilateral cryptorchidism and its effect on the testicular morphology, histology, accessory sex organs and sperm count in Laboratory Mice. J Hum Repro Sci 2013;6:106-110 PubMed .

17. Kidd SA, Eskenazi B, Wyrobek AJ. Effects of male age on semen quality and fertility: A review of the literature. Fertil Steril 2001;75:237-248 PubMed .

18. Bhattarai T, Chaudhuri P, Bhattacharya K, Sengupta P. Effect of progesterone supplementation on post-coital unilaterally ovariectomized superovulated mice in relation to implantation and pregnancy. Asian J Pharm Clin Res. 2014; 7(1):29-31.

19. Chandra AK, Goswami H, Sengupta P. Dietary calcium induced cytological and biochemical changes in thyroid. Env Toxicol Pharmacol 2012;34(2): 454-465.

20. Spandorfer SD, Avrech OM, Colombero LT, Palermo GD, Rosenwaks Z. Effect of parental age on fertilization and pregnancy characteristics in couples treated by intracytoplasmic sperm injection. Hum Reprod 1998;13:334338 PubMed .

21. Wyrobek AJ, Gordon LA, Burkhart JG, Francis MW, Kapp RW, Letz G, Malling HV, Topham JC, Whorton MD. An evaluation of human sperm as indicators of chemically induced alterations of spermatogenic function. A report of the U.S. Environmental Protection Agency Gene-Tox Program. Mutat Res 1983;115:73-148 PubMed .

22. Krajewska-Kulak E, Sengupta P. Thyroid function in male infertility. Front Endocrinol 2013;4:1-2 PubMed .

23. Lapido OA. [Seminal analysis in fertile and infertile Nigerian men.] Natl Aled Assoc 1980;72:785-789 PubMed. 24. Shaarawy M, Mahmoud KZ. Endocrine profile and semen characteristics in male smokers. Fertil Steril 1982;38:255-257 PubMed .

25. Sheriff DS. Setting standards of male fertility. I. Semen analyses in 1500 patients-a report. Andrologia 1983;15:687-692 PubMed .

26. Osegbe DN, Amaku EO, Nnatu SN. Are changing semen parameters a universal phenomenon? Eur Urol 1986;12:164-168 PubMed .

27. Sheriff DS. Semen analyses in Hansen's disease. Trans R Soc Trop Med Hyg 1987;81:113-114.

28. Kirei BR. Semen characteristics in 120 fertile Tanzanian men. East Afr Med J 1987;64:453-457 PubMed .

29. Sobowale OB, Akiwumi O. Testicular voltnie and seminal fluid profile in fertile and infertile males in Ilorin, Nigeria. IntJ Gynecol Obstet 1989;28:155-161 PubMed .

30. Nnatu SN, Giwa-Osagie OF, Essien EE. Effect of repeated semen ejaculation on sperm quality. Clin Exp Obstet Gynecol 1991;18:39-42.

31. Sheriff DS, Legnain M. Evaluation of semen quality in a local Libyan population. Indian J Physiol Pharmacol 1992;36:83-87.

32. Ugwuja EI, Ugwu NC, Ejikeme BN. Prevalence of low sperm count and abnormal semen parameters in male partners of women consulting at infertility clinic in Abakaliki, Nigeria. Afr J Reprod Health 2008;12:67-73 PubMed .

33. Feki NC, Abid N, Rebai A, Sellami A, Ayed BB, Guermazi M, Bahloul A, Rebai T, Ammar LK. Semen quality decline among men in infertile relationships: experience over 12 years in the South of Tunisia. J Androl 2009;30:541-547 PubMed .

34. Akande T, Isah HS, Sekoni VO, Pam IC. The Semen of Fertile Men in Jos, Nigeria. J Med Lab Sci 2011;20:3336 PubMed .

35. Jimoh AAG, Olawui TS, Olaiya Omotoso GO. Semen parameters and hormone profile of Men investigated for Infertility at Midland Fertility Centre, Ilorin, Nigeria. J Basic Appl Sci 2012;8:16-19 PubMed .

36. Hadjkacem Loukil L, Hadjkacem H, Bahloul A, Ayadi H. Relation between male obesity and male infertility in a Tunisian population. Andrologia 2015;47:282-285.

37. Stroup DF, Berlin JA, Morton SC, Olkin I, Williamson GD, Rennie D, et al. Meta-analyes of observational studies in epidemiology: a proposal for reporting. $J A M A$ 2000;283:2008-2012 PubMed .

38. Moher D, Liberati A, Tetzlaff J, Altman DG, The PRISMA Group. Preferred Reporting Items for System- 
atic Reviews and Meta-Analyses: The PRISMA Statement. PLoS Med 2009;6(7): PubMed e1000097.

39. Fisher RA, Yates R. Statistical Tables for Biological, Agricultural and Medical Research. Longman Group, London, 1974.

40. World Health Organization. Infertility: A tabulation of available data on prevalence of primary and secondary infertility. Programme on material and Child Health and Family Planning Division of Family Health. World Health Organization, Geneva, 1991.

41. Okonofua F, Menakaya U, Onemu SO, Omo-Aghaja LO, Bergstrom S. A Case-control study of risk factors for male infertility in Nigeria. Asian I Androl 2005;7:351-361 PubMed .

42. Ikechebula JI, Adinma JI, Orie EF, Ikegwuonu SO. High prevalence of male infertility in South Eastern Nigeria. J Obstet Gynaecol 2003;23:657-659 PubMed .

43. Akinloye O, Grommok J, Nieschlag E, Simoni M. Androgen receptor gene CAG and GGN polymorphysms in infertile Nigerian men. J Endocrinol Invest 2009;32:797804 PubMed.

44. Emokpae MA, Uadia PO, Omale-Itodo A, Orok TN. Male infertility and endocrinopathies in Kano, Northern Nigeria. Ann Afr Med 2007;6:61-67 PubMed .

45. Sengupta P, Borges Jr E, Dutta S, Krajewska-Kulak E. Decline in sperm count in European men during the past 50 years. Hum Exp Toxicol 2017: doi: 10.1177/09603327117703690.

46. Omo-Aghoja, L. Male Factor Infertility in Infertility and Assisted Conception in the Tropics. 1st Edition. Delta Reproductive Health Initiative and Research Center. 39-50. 2015.

47. Yeboah ED et al. Etiological factors of male infertility in Africa. Int J Fertil 1992; 37(5):300 PubMed -307.

48. Masarani M, Wazait H, Dinneen M. Mumps Orchitis. J Royal Soc Med 2006;99(11): 573 PubMed -575.

49. Inhorn MC, Buss KA. Ethnography, Epidermiology and Infertility in Egypt. Social Sci Med 1994;39(5):671 PubMed -686.

50. Okonofua F, Omo-Aghoja LO, Menakaya U, Onemu SO, Bergstrom S. A Case-Control Study of Risk Factors for Male Infertility in Southern Nigeria. Trop J Obstet Gynaecol 2005, 22: 136-143.

51. Emanuelle MA, Emanuelle NV. Alcohol and the male reproductive system. Alcohol Res Health 2001;25: 282-287 PubMed .

52. Abarikwu SO. Causes and Risk Factors for Male-Fac- tor Infertility in Nigeria: A Review. Afr J Reprod Health 2013:17(4): 150-166.

53. Emsley J. Nature's building blocks: An A-Z guide to the elements. Oxford [Oxfordshire]: Oxford University Press, 2001, pp. 76.

54. Angwafo PF. Migration and prostate cancer: an international perspective. J Nat Med Assoc 1998;90: S720-723

55. Omu AE, Dashtu H, Mohammed AT et al. Significance of trace elements in seminal fluid of infertile men. Nutrition 1995;11: 502-505 PubMed .

56. Sram BI, Binkova B, Dejmek J et al. Teplice program-the impact of air pollution in human health. Env Health Persp 1996: 104: 699-714 PubMed

57. Olayemi FO. A review on some causes of male infertility. Afr J Biotechnol 2010:20: 2834-2842 PubMed .

58. Emopkae MA, Uadia PO, Omale-Itodo A, Orok TN. Male Infertility and Endocrinopathies in Kano, Northwestern Nigeria. Ann Afr Med 2007;6: 64-67 PubMed .

59. Ozoemena OFN, Ezugworie JO, Mbah AU, Ejezie FE. Abnormalities of Pituitary gonadal axis among Nigerian males with infertility: Study of patterns and possible etiologic interrelationships. J Urol. 2011;3:133-137 PubMed .

60. Geidam AD, Yawe KDT, Adebayo AEA et al. Hormonal Profile of men investigated for infertility at the University of Maiduguri in Northern Nigeria. Singapore Med J 2008;49:538-541 PubMed.

61. Muthuuri JM. Male infertility in a private Kenyan hospital. East African Medical Journal 2005;82:362-366.

62. Pasqualotto FF, Pasqualotto EB, Sobreiro BP et al. Clinical diagnosis in men undergoing infertility investigation in a University hospital. Urol Int 2006;76:122-125 PubMed .

63. Sinclair S. Male Infertility: Nutritional and environmental consideration. Alt Med Rev 2000;5:28-38 PubMed. 64. Underwood BA, Smitasiri S. Micronutrients malnutrition: policies and programs for control and their implications. Ann Rev Nutr 1999; 19: 303-324 PubMed .

65. Dabrowski K, Ciereszko A. Ascorbic acid protects against male infertility in a teleost fish. Experientia 1996;52:97-100 PubMed.

66. Ebunusun MO, Solademi BA, Shittu OB et al. Plasma and semen ascorbic levels in spermatogenesis. West Afr J Med 2004;23:290-293 PubMed .

67. Akinloye O, Arowojolu AO, Shittu OB et al. Selenium status of idiopathic infertile Nigerian males. Biol Trace Elem Res 2005;104:9-18 PubMed . 
68. Slutsky M, Levin JL, Levy BS. Azoospermia and Oligospermia among a large cohort of DBCP applicators in 12 countries. Int J Occup Env Health 1999;5:116-122

69. Rupa DS, Reddy PP, Reddy OS. Reproductive performance in population exposed to pesticides in cotton fields in India. Environ Res 1991;55:123-128 PubMed .

70. Lerda D, Rizzi R. Study of Reproduction function in persons occupationally exposed to 2, 4-dichlorophenoxyacetic acid (2, 4-D). Mutat Res 1991;262:47-50 PubMed .
71. Ibeh IN, Uraih N, Ogonar JI. Dietary exposure to aflatoxin in human male infertility in Benin City, Nigeria. Int J Fert 1994;39:208-214 PubMed .

72. Sheiner EK, Sheiner E, Hammel RD et al. Effect of occupational exposures on male fertility: Literature Review. Indus Health 2003;41:55-62 PubMed .

73. Foster WJ, Rowley MJ. Testicular biopsy in the study of gorilla infertility. Am J Primatol 2005;3:121-125 PubMed. 